\title{
Copepod egg production in the NW Mediterranean: effects of winter environmental conditions
}

\author{
Albert Calbet*, Enric Saiz, Miquel Alcaraz \\ Departament de Biologia Marina i Oceanografia, Institut de Ciències del Mar, CMIMA (CSIC), Passeig Marítim de la \\ Barceloneta, 37-49, 08003 Barcelona, Catalonia, Spain
}

\begin{abstract}
In the NW Mediterranean the highest abundance of phytoplankton is found during late winter, when temperatures are low. During summer, on the other hand, temperatures are high and phytoplankton abundance low, resulting in low copepod egg production rates (EPR). Despite the apparently better food conditions for copepod growth during winter, we lack information on copepod EPR during the cold season and on the possible effect temperature has on inhibiting this metabolic rate. To solve this uncertainty, a study was carried out to assess the effects exerted by the winter environmental conditions on the EPR of 3 representative planktonic copepod species of the NW Mediterranean (Centropages typicus, Clausocalanus lividus, Acartia clausi). The data were collected during 2 oceanographic cruises in March 1999 (Hivern-99) and January-February 2000 (Hivern-00) and the results compared to those of typical summer conditions. During the Hivern-99 cruise the phytoplankton abundance was very high (ranging from 1 to $1.5 \mu \mathrm{g}>5 \mu \mathrm{m}$ chlorophyll $a$ [chl a] $\mathrm{l}^{-1}$ ), indicating bloom conditions. During the Hivern-00, the phytoplankton bloom had not yet developed, evident by the $\mathrm{chl}$ a concentration of $\sim 0.5 \mu \mathrm{g}^{-1}$. The recorded EPR during Hivern-99 were amongst the highest for the studied species, and the clearance rates deduced from them indicate a shorter (phytoplankton - copepods) food web during the winter phytoplankton bloom than for the rest of the year, when the planktonic trophic interactions take place through a longer microbial food web.
\end{abstract}

KEY WORDS: Zooplankton $\cdot$ Copepod $\cdot$ Egg production $\cdot$ Centropages $\cdot$ Clausocalanus $\cdot$ Acartia Mediterranean · Winter $\cdot$ Summer $\cdot$ Density front $\cdot$ Physical-biological coupling

Resale or republication not permitted without written consent of the publisher

\section{INTRODUCTION}

The NW Mediterranean is a highly dynamic oligotrophic marine area, subjected to important climatic forcing expressed in alternate periods of thermal stratification and vertical mixing. During summer, while the heating of the surface water progresses, thermal stratification becomes apparent, resulting in a mixed layer above the thermocline. In this layer nutrients are rapidly depleted by autotrophic organisms. In winter, the combined effect of cooling and wind forcing breaks down stratification, and nutrients from deeper waters reach the surface layers. While in more northerly seas the first phytoplankton bloom after winter mixing oc-

*E-mail: acalbet@icm.csic.es curs in spring, in the western Mediterranean, temperature and irradiance conditions allow the advancement of phytoplankton to January or February (Estrada et al. 1999, Calbet et al. 2001). Hydrographic mesoscale structures as well as their effects on biological phenomena are also more conspicuous in winter. Examples include the permanent shelf-break density front situated at the seaward border of the Liguro-Provençal-Catalan current, which runs southwest close to the mainland coast (Castellón et al. 1991), and the dome-like structure between the front and the Balearic Islands. These hydrographic structures may determine phytoplankton distribution (Margalef \& Estrada 1987, Estrada et al. 1999) and primary production (Estrada \& Margalef 1988), and influence zooplankton distribution, metabolism and feeding rates (Alcaraz \& Packard 1989, Saiz 
et al. 1992, Alcaraz et al. 1994, Calbet et al. 1996). It is thus evident that climate mediates the physical and biological characteristics of the water column, yielding 2 contrasting environments, 1 in summer and 1 in winter. While in summer temperature is high and phytoplankton abundance low, in late winter temperature is low and phytoplankton abundant. Recent predictive models (Huntley \& Lopez 1992, Hirst \& Lampitt 1998) consider temperature as the main environmental factor controlling the growth rates of marine copepods. If this is correct, copepod production rates in summer should be higher than in winter. Despite the expected coupling between hydrographic mesoscale structures and biological processes during winter, all of the available data on zooplankton secondary production in the offshore waters of the NW Mediterranean come from summer (Calbet et al. 1996, Saiz et al. 1999), thus preventing us from fully testing our hypothesis. Certainly, there are studies characterizing seasonal cycles of copepod egg production (Le Ruyet-Person et al. 1975, Razouls 1982, Ianora \& Scotto di Carlo 1988, Ianora \& Butino 1990, Ianora et al. 1992, Halsband-Lenk et al. 2001). However, these works are restricted to coastal areas, highly affected by terrestrial influences (e.g. rivers, sewage flow).

The previous studies of copepod production rates in thermally stratified open NW Mediterranean waters show variable results. Calbet et al. (1996) reported very low egg production rates during summer 1993. On the other hand, in a more intensive survey in the same area in summer 1995, Saiz et al. (1999) found relatively higher production rates. This later study concluded that consumption of phytoplankton alone could not maintain the observed copepod production rates. The importance of autotrophic food sources in the feeding of zooplankton populations is, however, uncertain during winter, when phytoplankton are more productive and numerous (Estrada et al. 1999). Here we present data on phyto- and zooplankton biomass and distribution and associated copepod egg production rates, taken as an indicator of their secondary production. Our aim was to characterize a typical winter zooplankton population of the NW Mediterranean and to study their relationships with physical (temperature, hydrographic singularities) and biological (phytoplankton abundance and size structure) variables. We emphasize community structure and copepod production rates, and compare them with previous studies in the same area during the thermal stratification period.

\section{MATERIALS AND METHODS}

Area surveyed. The study was carried out in the Catalan Sea (NW Mediterranean) on 2 cruises on the
RV 'García del Cid' during winter 1999 (Hivern-99, 1 to 15 March) and 2000 (Hivern-00, 28 January to 11 February). Before the study, a survey of a grid of stations provided the physical setting. The fixed biological stations were located along 2 transects, 1 perpendicular to the shoreline of Barcelona (B) and 1 further north, perpendicular to the shoreline of Palamós (P). Three biological stations were selected in each transect as representatives of contrasting hydrographic situations: 1 station in coastal waters (C), a second on the shelfbreak, at the margin of the Liguro-Provençal-Catalan current and coincident with the density front $(\mathrm{F})$, and a third station in more oceanic waters $(\mathrm{O})$ in the domelike structure between the NE Spanish coast and the Balearic Islands (Fig. 1). When possible, the stations were visited twice during the cruises. In order to obtain a quasi-synoptic picture of the zooplankton distribution in relation to the hydrographic structure and phytoplankton distribution, the Barcelona transect was intensively surveyed during daylight hours of a single day on the Hivern-00 cruise. CTD casts (without water samples) and vertical plankton net tows were taken approximately every $16 \mathrm{~km}$ (8 km near the frontal area), along a transect of $85 \mathrm{~km}$.

Description of sampling. Temperature, salinity and in situ fluorescence were recorded with a Seabird-25 CTD equipped with a Sea Tech fluorometer. Water samples for chlorophyll $a(\mathrm{chl} a)$ analyses $(0$ to $80 \mathrm{~m})$ were collected in the afternoon at 10 to $20 \mathrm{~m}$ depth intervals using a rosette with 101 Niskin bottles. For total chl $a, 100 \mathrm{ml}$ of water was filtered under low vacuum pressure $(<100 \mathrm{~mm} \mathrm{Hg})$ through Whatmann glass fiber filters (GF/F, $25 \mathrm{~mm}$ diameter). For the $>5 \mu \mathrm{m}$ fraction, $200 \mathrm{ml}$ samples were filtered through $5 \mu \mathrm{m}$ pore-size polycarbonate Nucleopore ${ }^{\mathrm{TM}}$ filters $(25 \mathrm{~mm}$ diameter). After filtration, the filters were frozen in liquid nitrogen and stored at $-80^{\circ} \mathrm{C}$ until analysis. Chl a was determined by fluorometry on acetone extracts without acidification (Welschmeyer 1994), which provides sensitive measurements of extracted chl a plus phaeopigments. For the sake of simplicity and to standardize the nomenclature with previous studies using the same technique we will refer to chl $a$ when showing pigment concentrations obtained by this method.

For the determination of mesozooplankton abundance, a double WP2 net $(56.5 \mathrm{~cm}$ mouth diameter, $200 \mu \mathrm{m}$ mesh size) was towed vertically at $60 \mathrm{~m} \mathrm{~min}^{-1}$ from $200 \mathrm{~m}$ depth to surface (or from bottom to surface for shallower stations). Since no flowmeter was used, the volume filtered was calculated as the meters released off a cable times the fishing area. Mesozooplankton abundance was estimated by counting and identifying under stereomicroscope around 300 individuals per sample. To collect live zooplankton, the nets were towed from $80 \mathrm{~m}$ depth (or near bottom 
when shallower) to surface at low speed $\left(10 \mathrm{~m} \mathrm{~min}^{-1}\right)$. A 51 plastic bag was used instead of a filtering cod-end to reduce organismal stress or damage due to sampling. Once on deck, the contents of the bags were poured in coolers for further sorting.

Egg production experiments. Copepod egg production rates (EPR) were determined, when possible, for the free-spawning copepods Centropages typicus and Clausocalanus lividus. During the Hivern-99 cruise some additional experiments were carried out with Acartia clausi. Female copepods were sorted by species using a wide-mouth Pasteur pipette under stereomicroscope and transferred to $625 \mathrm{ml}$ Pyrex bottles in groups of 4 (occasionally 3 or 5). The bottles had been previously filled with water from the fluorescence maximum screened through $100 \mu \mathrm{m}$ nitex mesh by reverse filtration in order to remove large zooplankters. Usually each experiment consisted of 4 replicate bottles for each species. Four additional control bottles without copepods were set to take into account any eggs present in the water after the initial screening.

The experimental bottles were incubated in a deck incubator cooled with circulating surface seawater (temperature $=12.7$ to 14.2 and 11.9 to $13.4^{\circ} \mathrm{C}$ for
Hivern-99 and Hivern-00, respectively) and dim light, provided by a dark mesh that retained $99 \%$ of surface light intensity. The bottles were gently turned upside down several times during the incubations to reduce settling of algae. After ca. $24 \mathrm{~h}$ the contents of the bottles were filtered onto $20 \mu \mathrm{m}$ sieves, the animals checked for activity (mortality $=0.6 \%$ ), and eggs and copepods preserved for counting and measuring later in the laboratory. When empty shells appeared due to egg cannibalism, they were also accounted for. Cephalothorax length of the copepods was measured under the stereomicroscope. Female carbon content was estimated from their size and length-weight relationships according Davis \& Alatalo (1992) for Centropages typicus, and Durbin \& Durbin (1978) for Clausocalanus sp. and Acartia clausi. Dry weight was converted into carbon content using a factor of 0.4 (Parsons et al. 1984). Egg diameter was determined using an inverted microscope with the aid of an ocular micrometer, and egg weight was obtained using the equation of Huntley \& Lopez (1992). Egg production rates were expressed as individual rates (eggs laid per female and day) and specific growth rates $\left(g, \mathrm{~d}^{-1}\right)$ as $g=\ln (G+1)$, were $G$ is the finite weight-specific fecundity (Chisholm \& Roff 1990).

Fig. 1. Map of the study area with the position of the surveyed stations. $\mathrm{B}=$ Barcelona $\mathrm{P}=$ Palamós, $\mathrm{C}=$ coastal $\mathrm{F}=$ frontal and $\mathrm{O}=$ oceanic

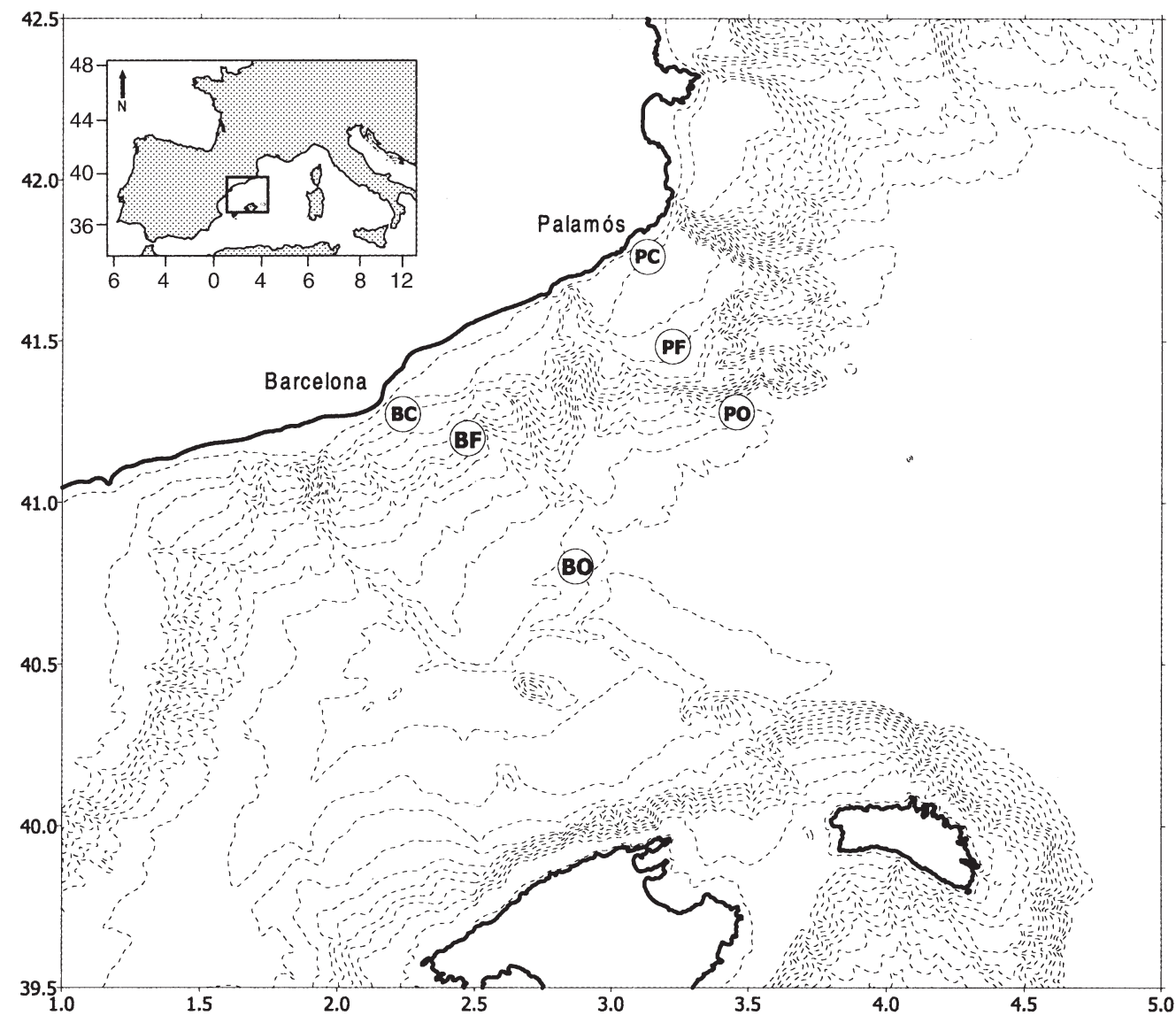




\section{RESULTS}

\section{Environmental condition}

The distribution of density $\left(\sigma_{t}\right)$ and fluorescence (volts) across the Barcelona transect (Hivern-00) in Fig. 2 can be considered to represent a typical winter situation, and will be used to characterize the main hydrographic singularities. The Catalan front appears clearly in the $\sigma_{\mathrm{t}}$ plot at 30 to $35 \mathrm{~km}$ from the Catalan coast (Fig. 2A). Farther east, the intrusion of less saline Atlantic waters is indicated by the vertical density gradient. Between these 2 conditions the pycnoclines are dome-shaped.

Phytoplankton distribution (fluorescence) was highly influenced by the physical dynamics, with highest concentrations within the first $40 \mathrm{~m}$ in the vicinity of the Catalan front (Fig. 2B), coinciding with the dome-like structure. The lowest values were in the area influenced by the nutrient-depleted surface Atlantic waters. This pattern, however, appears to be masked by the remarkable temporal variability of average depth-integrated chl a concentration for the repeated visits to the biological stations (coastal, frontal, oceanic; Fig. 3). In general, values of chl a concentration were higher for Hivern-99 than for Hivern-00. During the Hivern99 cruise the contribution of $>5 \mu \mathrm{m}$ chl a was sig-
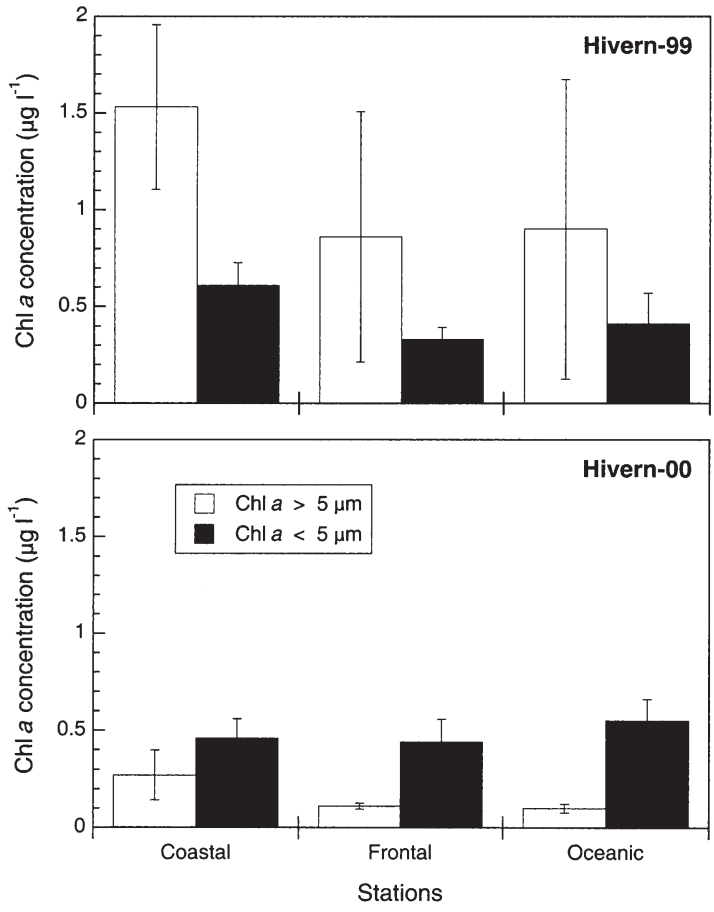

Fig. 3. Average depth-integrated chl a concentration for the different stations surveyed during the Hivern-99 and Hivern-00 cruises. The stations of the transects corresponding to Palamós and Barcelona of each cruise were grouped (mean $\pm 1 \mathrm{SE}$ ) into coastal, frontal and oceanic stations
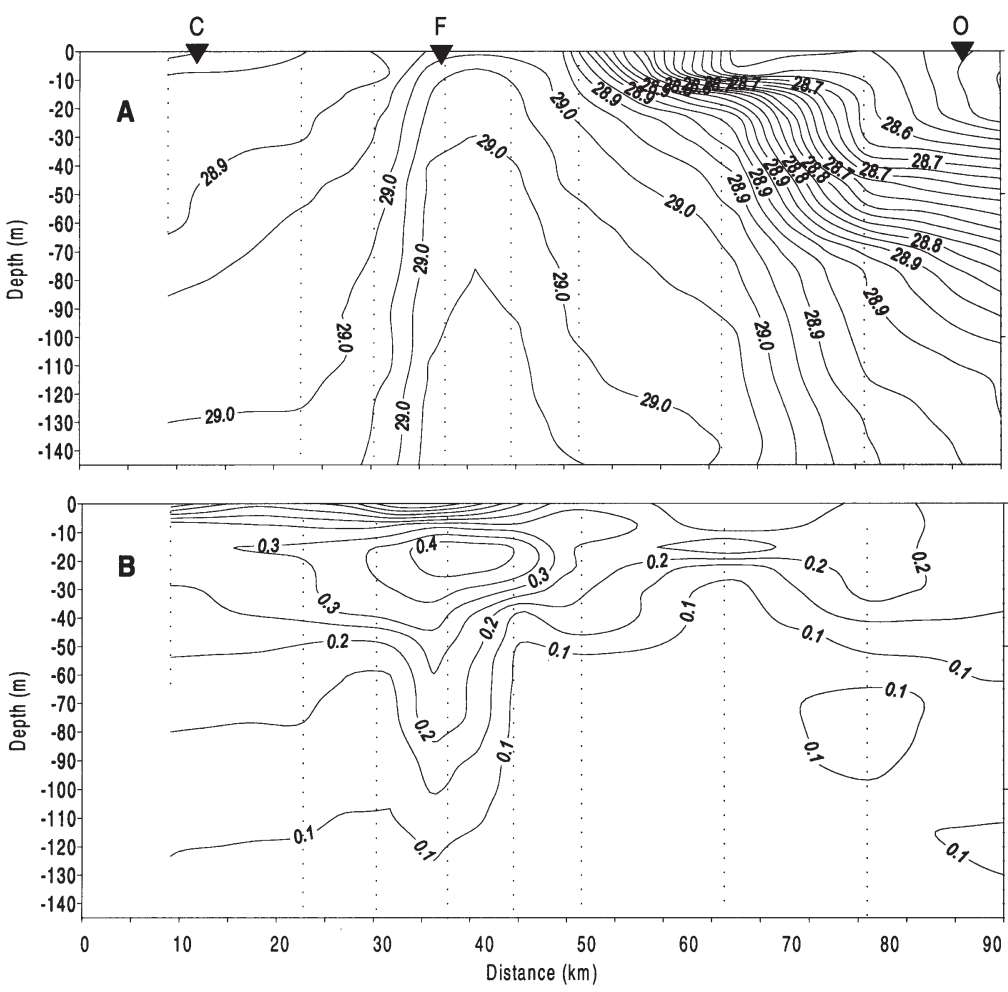

Fig. 2. (A) Density $\left(\sigma_{t}\right)$ and (B) fluorescence (volts) distributions for the Barcelona transect (Hivern-00 cruise). The position of the biological stations in the transect is also indicated nificantly higher $(\mathrm{p}<0.0001)$ than during Hivern-00 (64\% and $25 \%$, respectively), when most of the phytoplanktonic community corresponded to autotrophs $<5 \mu \mathrm{m}$.

Zooplankton abundance and taxonomic composition were determined for the Hivern00 Barcelona transect (Fig. 4). The main trend was a decrease in abundance from coastal to open-ocean waters up to $\sim 55 \mathrm{~km}$ from the coast. Farther east, the abundance of organisms increased again, reaching values similar to those obtained in more coastal waters $\left(\sim 1000\right.$ ind $\left.\mathrm{m}^{-3}\right)$. The community was dominated by calanoid copepods (68\%), followed in abundance by cyclopoids and appendicularians (14 and $6 \%$, respectively).

\section{Copepod EPR}

The values of copepod EPR for the studied species (Centropages typicus, Clausocalanus lividus and Acartia clausi) averaged for all coastal, frontal and oceanic stations of each cruise are represented in Fig. 5. During the Hivern-99 cruise only A. clausi 
EPR appeared to be significantly different between stations (ANOVA, p < 0.002), EPR of coastal and frontal stations being higher than the oceanic ones. In contrast, during Hivern-00, C. lividus displayed higher EPR at oceanic stations $(\mathrm{p}<0.05)$. For C. typicus the differences in EPR between stations for the 2 years were not statistically significant. It is worth mentioning that the highly variable EPR observed amongst replicates for C. lividus were due in part to the frequency of replicate bottles in which

Table 1. Weight-specific growth rates $\left(\mathrm{d}^{-1}\right)$ found during the study for the different copepod species considered. The stations of the transects corresponding to Palamós and Barcelona of each cruise were grouped (mean \pm 1 SE) into coastal, frontal and oceanic stations

\begin{tabular}{|llll|}
\hline Species & Station & Hivern-99 & Hivern-00 \\
\hline $\begin{array}{l}\text { Centropages } \\
\text { typicus }\end{array}$ & Coastal & $0.13 \pm 0.023$ & $0.09 \pm 0.011$ \\
& Frontal & & $0.10 \pm 0.017$ \\
Clausocalanus & Oceanic & 0.12 & $0.08 \pm 0.010$ \\
lividus & Coastal & $0.05 \pm 0.020$ & $0.01 \pm 0.004$ \\
& Frontal & $0.02 \pm 0.19$ & $0.01 \pm 0.005$ \\
Acartia clausi & Oceanic & $0.03 \pm 0.016$ & $0.02 \pm 0.005$ \\
& Coastal & $0.20 \pm 0.015$ & \\
& Frontal & $0.13 \pm 0.023$ & \\
& Oceanic & $0.10 \pm 0.019$ & \\
\hline
\end{tabular}

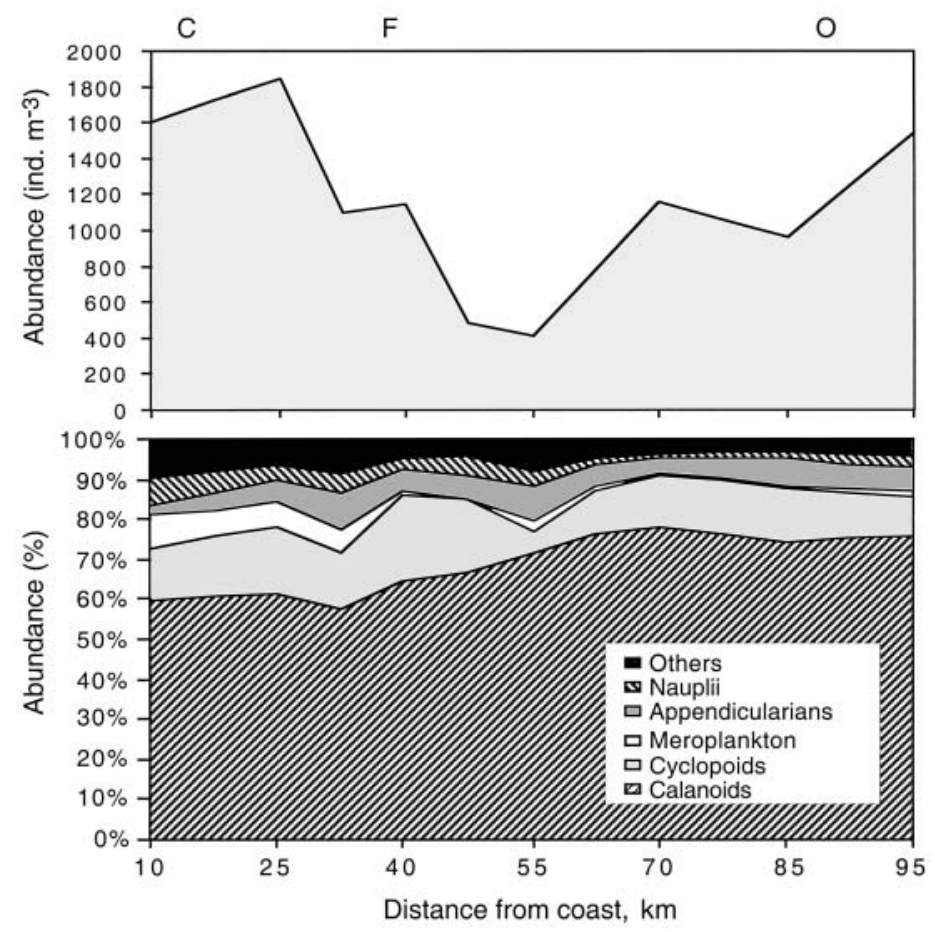

Fig. 4. Zooplankton abundance and community composition along the Barcelona transect (Hivern-00). The position of the main sampled stations is indicated. C: coastal; F: frontal;

$$
\text { O: oceanic }
$$

no eggs were laid. Weight specific growth rates (Table 1) were higher for A. clausi (Hivern-99) and C. typicus (both Hivern-99 and Hivern-00). No clear differences were observed between coastal, frontal and oceanic stations for both years. The body size of the copepods studied is summarized in Table 2. Copepod cephalothorax was significantly longer in Hivern-99 than in Hivern-00 for all species (ANOVA, $\mathrm{p}<0.0001$ ). No significant differences were found between coastal, frontal and oceanic stations.

Table 2. Cephalothorax length $(\mu \mathrm{m} \pm \mathrm{SE}$ ) for the species studied. The stations of the transects corresponding to Palamós and Barcelona of each cruise were grouped (mean $\pm 1 \mathrm{SE}$ ) into coastal, frontal and oceanic stations

\begin{tabular}{|llll|}
\hline Species & Station & Hivern-99 & Hivern-00 \\
\hline $\begin{array}{l}\text { Centropages } \\
\text { typicus }\end{array}$ & Coastal & $1245 \pm 19.8$ & $1173 \pm 11.8$ \\
& Frontal & & $1137 \pm 6.9$ \\
Clausocalanus & Oceanic & $1313 \pm 1.2$ & $1213 \pm 7.3$ \\
lividus & Coastal & $1256 \pm 13.6$ & $1190 \pm 8.0$ \\
& Frontal & $1303 \pm 19.1$ & $1206 \pm 12.0$ \\
Acartia clausi & Oceanic & $1270 \pm 8.9$ & $1196 \pm 5.7$ \\
& Coastal & $1009 \pm 7.5$ & \\
& Frontal & $989 \pm 3.2$ & \\
& Oceanic & $988 \pm 7.6$ & \\
\hline
\end{tabular}
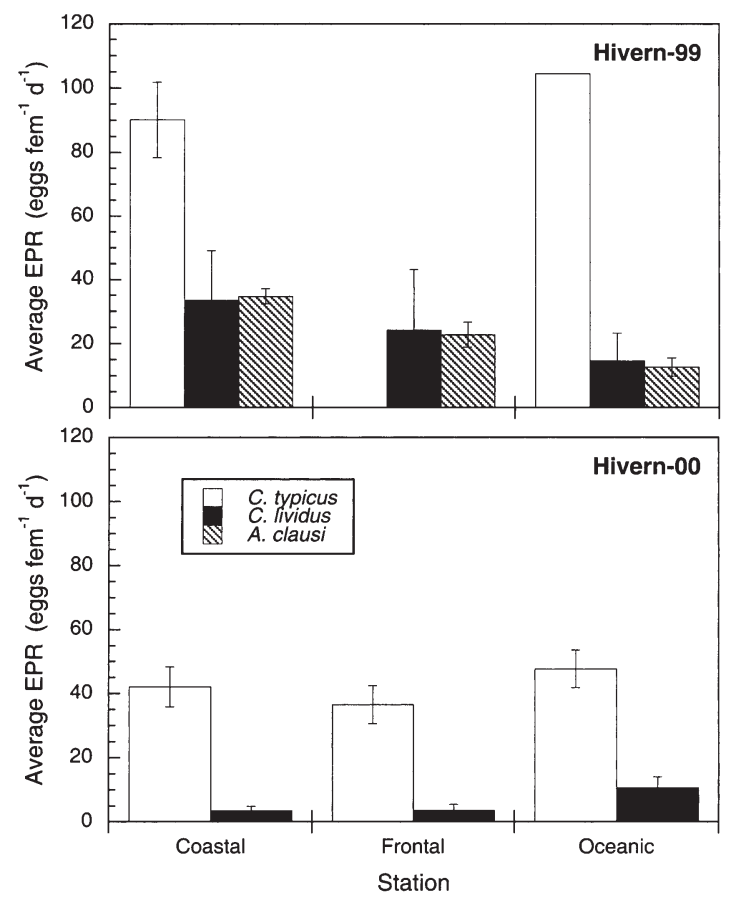

Fig. 5. Average egg production rates in 3 stations for the copepod species studied. The stations of the transects corresponding to Palamós and Barcelona of each cruise were grouped (mean $\pm 1 \mathrm{SE}$ ) into coastal, frontal and oceanic stations 
The relationships between chl $a$ and EPR and weightspecific growth rates of Centropages typicus, Clausocalanus lividus and Acartia clausi are presented in Figs. 6 \& 7, respectively. Overall, winter C. typicus pro- duction rates seemed to follow an asymptotic model (simplest best fit model), especially for $>5 \mu \mathrm{m} \mathrm{chl} a$, indicating saturation of EPR above values of $\sim 0.5 \mu \mathrm{g}$ chl a $>5 \mu \mathrm{m}$. C. lividus did not show a clear food-
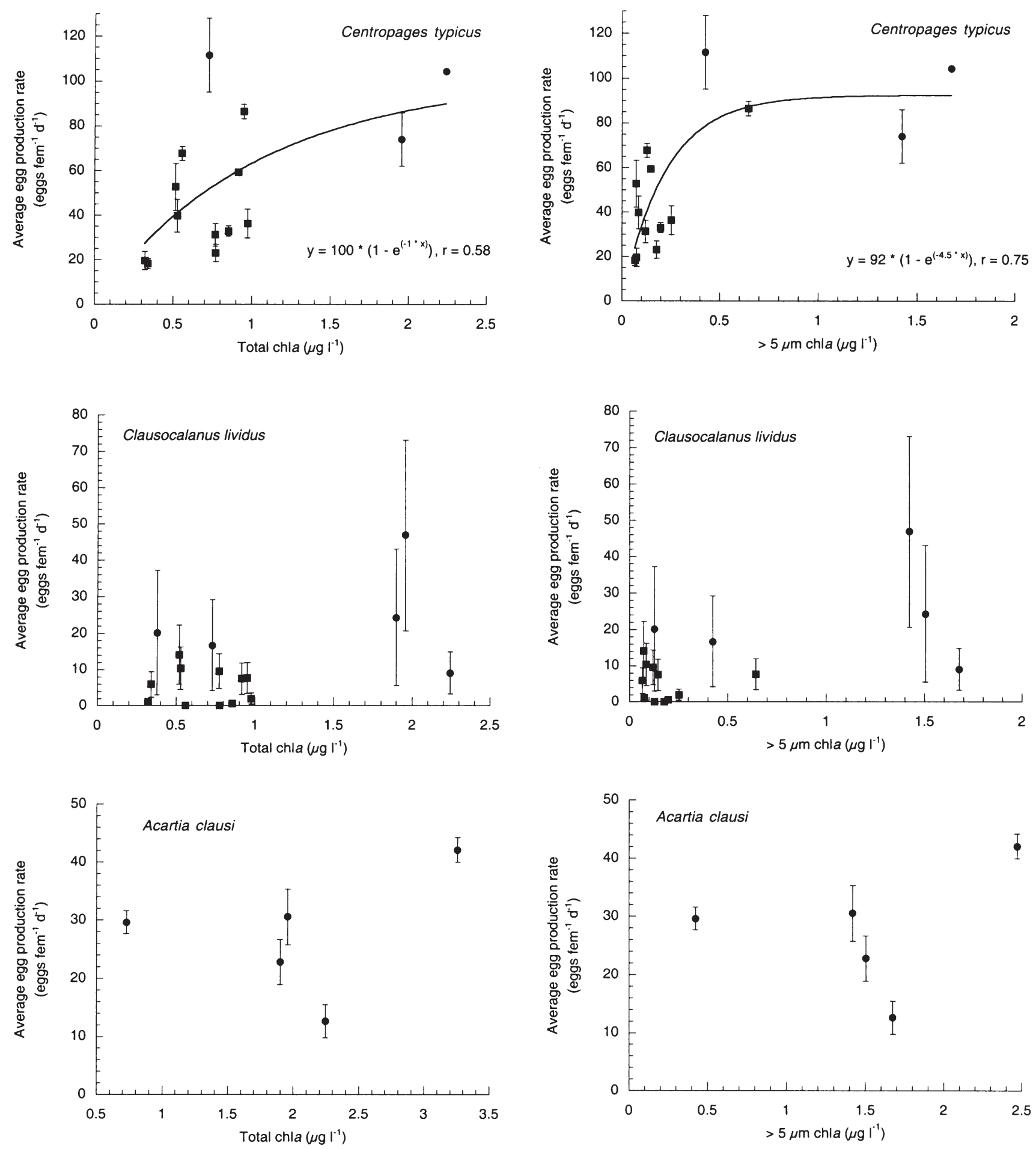

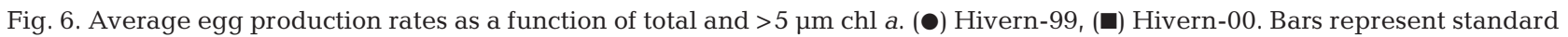
error computed between replicate bottles for each visit to the stations 
dependent saturation pattern, probably due to the high variability found between replicates. No significant correlation with any size-fraction of chl a was found for A. clausi.
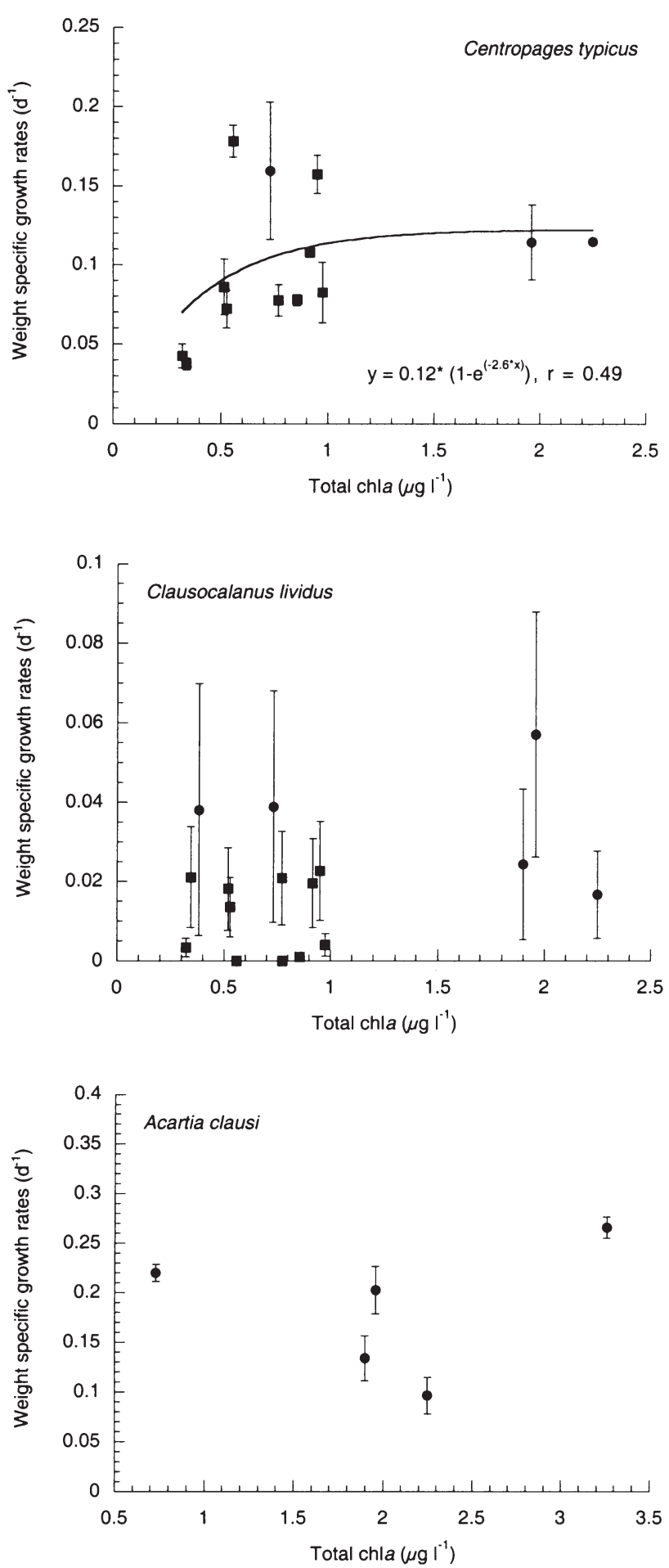

\section{Previous data in the area for the summer season}

One of the objectives of this paper was to compare the dynamics of the winter copepod populations with
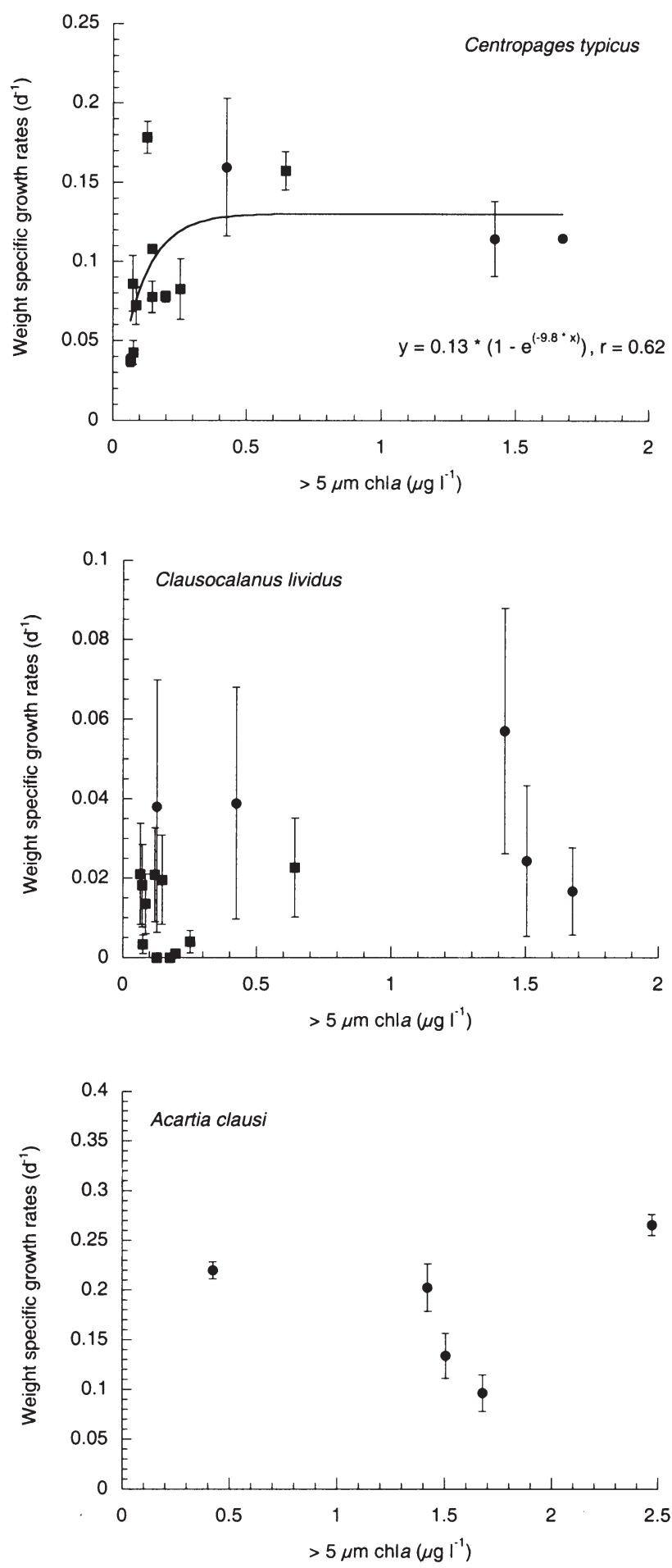

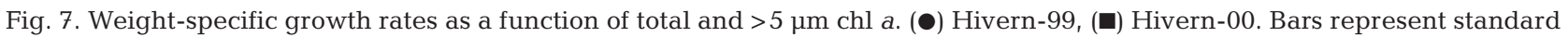
error computed between replicate bottles for each visit to the stations 
Table 3. Daytime chl a concentration (total and $>5 \mu \mathrm{m}, \mathrm{mg} \mathrm{m}^{-3}$ ) and mesozooplankton abundance (ind. $\mathrm{m}^{-3}$ ) during summer in the NW Mediterranean. Data from Calbet et al. (1996) (summer 1993) and Saiz et al. (1999) (summer 1995). Values correspond to the average concentration of chl $a$ in the first $90 \mathrm{~m}$ (summer 1993) and 60 to $70 \mathrm{~m}$ of the water column (summer 1995), and to the average abundance of zooplankton from $200 \mathrm{~m}$ (when possible) to surface

\begin{tabular}{|lccc|}
\hline & Total chl $a$ & $>5 \mu \mathrm{m} \mathrm{chl} \mathrm{a}$ & Zooplankton \\
\hline Summer 93 & & & \\
Coastal & & & 773 \\
Frontal & 0.34 & & 493 \\
Oceanic & 0.43 & & 260 \\
Summer 95 & & & \\
Coastal & 0.36 & 0.18 & 1013 \\
Frontal & 0.39 & 0.20 & 1373 \\
Oceanic & 0.46 & 0.14 & 809 \\
\hline
\end{tabular}

previous knowledge of the zooplankton dynamics in the study area during summer. For comparison, a summary of 2 studies (Calbet et al. 1996, Saiz et al. 1999) dealing with zooplankton community structure and production rates in open waters of the NW Mediterranean (to our knowledge the only ones) is shown in Tables 3 \& 4 . For methodological details we refer to the original articles. Table 3 illustrates the community biomass and abundance of phytoplankton and mesozooplankton, respectively. The chl a concentrations were similar during both years (1993 and 1995), while the biomass of zooplankton consumers supported by this chl a was higher in 1995. In general, chl a concentra-

Table 4. Metasome length $(\mu \mathrm{m})$, mean egg production rates (EPR, eggs fem ${ }^{-1} \mathrm{~d}^{-1}$ ), and mean weight-specific growth rates $\left(\mathrm{g}, \mathrm{d}^{-1}\right)$ of Acartia clausi, Centropages typicus and Clausocalanus lividus during summer in the NW Mediterranean. Data from Calbet et al. (1996) (summer 93) and Saiz et al. (1999) (summer 95)

\begin{tabular}{|clrrr|}
\hline & & Metasome & EPR & $\mathrm{g}$ \\
\hline Summer 93 & & & & \\
C. typicus & Coastal & & & \\
& Frontal & 990 & 10.9 & 0.01 \\
& Oceanic & 990 & 11.7 & 0.10 \\
A. clausi & Coastal & & & \\
& Frontal & 840 & 1.8 & 0.02 \\
& Oceanic & 840 & 1.9 & 0.03 \\
Summer 95 & & & & \\
C. typicus & Coastal & 947 & 15.4 & 0.09 \\
& Frontal & 988 & 19.7 & 0.09 \\
& Oceanic & 917 & 4.9 & 0.03 \\
C. lividus & Coastal & 1129 & 10.9 & 0.03 \\
& Frontal & 1125 & 7.2 & 0.02 \\
& Oceanic & 1080 & 2.2 & 0.01 \\
\hline
\end{tabular}

tions during summer were similar to those of Hivern00, but almost 1 order of magnitude lower than during the Hivern-99 cruise. Zooplankton abundance reported for the period of thermal stratification was not much different from that observed in the present study. EPR, except for Clausocalanus lividus during Hivern00, were also much lower in summer (both years) than in the present study (Table 4). These differences in EPR, however, were smoothed when translated into weight-specific growth rates, due to differences in female body sizes. The winter specimens of $C$. lividus, Acartia clausi and Centropages typicus were 10, 15 and $21 \%$ longer than the summer ones, respectively. As a consequence, weight-specific growth rates for $C$. typicus in winter were on average only $62 \%$ higher than in summer, although differences were not significant (ANOVA test, $\mathrm{p}>0.08$ ). For C. lividus, weightspecific growth rates during summer were at the lower end of the range of winter values. For A. clausi, winter weight-specific growth rates were clearly much higher than summer values.

\section{DISCUSSION}

\section{Winter scenario}

The presence of a late-winter phytoplankton bloom is a recurrent feature of Mediterranean waters (Cacciamani et al. 1992, Modigh et al. 1996, Mura et al. 1996, Duarte et al. 1999, Calbet et al. 2001), although there is interannual variability in its timing. That would explain the low chl a values during the Hivern-00 cruise (January-February) compared with Hivern-99 (March), when the bloom was fully developed. This is supported by the higher primary production rates measured during Hivern-99 (Morán \& Estrada unpubl.). The influence of the different hydrographic structures of the Catalan frontal system on the distribution of the zooplankton community is also clear. However, the area of maximum phytoplankton did not coincide with the maximum zooplankton abundance. Such a contrast has been previously described in the same area (Calbet et al. 1996) and in other frontal structures (Uye et al. 1992), and could be attributed to a higher zooplankton mortality due to predation (Uye et al. 1992) or to removal of organisms by advection.

The effect of the frontal structure on copepod dynamics appears only in the quasi-synoptic data from the Barcelona transect in the Hivern-00 cruise; no apparent differences were observed in copepod EPR among the fixed biological stations (coastal, frontal, oceanic). Again, temporal variability masked any trend. At least indirectly, the structures of the frontal system must have affected EPR through changes in 
chl a concentration (and very likely other seston components).

The response of EPR to changes in chl a concentration was different for the 3 copepod species. EPR of Centropages typicus saturated around $0.5 \mu \mathrm{g} \mathrm{l}^{-1}$ of $>5 \mu \mathrm{m}$ chl $a$, but in the other species the response was different. In fact, for Acartia clausi, EPR seemed to be independent of chl a concentration, although this could be due to the few data available.

Consistent with the high values of chl a found during the winter-bloom conditions during the Hivern-99 cruise, the maximum EPR obtained were also very high. For Centropages typicus and Acartia clausi they were close to the maximum reported productions for similar temperatures (Razouls 1975, Dagg 1977, Ianora et al. 1992, for C. typicus; Uye 1981, for A. clausi). Even though very variable, the maximum EPR of Clausocalanus lividus (around 100 eggs fem ${ }^{-1} \mathrm{~d}^{-1}$ for some individual bottles) are higher than previous data on Clausocalanus species (Hopcroft \& Roff 1998, Saiz et al. 1999). This species, although a free spawner (Saiz \& Calbet 1999), belongs to a typically egg-sac-bearing genus. Possibly, despite its lack of an egg sac, its clutches are produced at long intervals, typical of eggsac-carrying copepods. This could explain the fact that after $24 \mathrm{~h}$ incubation in some of the 4 to 5 replicated bottles very few eggs (or no eggs) were laid, while in others, where by chance a clutch was released, estimated EPRs were extremely high.

Additional information that may be derived from secondary production is that of the carbon consumed inferred from the carbon produced, and its relation with (autotrophic) carbon availability. Table 5 shows the estimated clearance rate on phytoplankton needed to maintain the observed specific growth rates if copepods were considered strictly herbivorous. The calculations have been done assuming a phytoplankton car-

Table 5. Predicted clearance rates on the $>5 \mu \mathrm{m} \mathrm{chl} \mathrm{a}(\mathrm{ml}$ swept clear ind.$^{-1} \mathrm{~d}^{-1}$ ), based on the food ingestion required to maintain the egg production rates found during the study. The stations of the transects corresponding to Palamós and Barcelona of each cruise were grouped (mean $\pm 1 \mathrm{SE}$ ) into coastal, frontal and oceanic stations

\begin{tabular}{|llcc|}
\hline Species & Station & Hivern-99 & Hivern-00 \\
\hline $\begin{array}{c}\text { Centropages } \\
\text { typicus }\end{array}$ & Coastal & $262 \pm 85.2$ & $321 \pm 26.2$ \\
& Frontal & & $617 \pm 86.6$ \\
Clausocalanus & Oceanic & 116 & $1046 \pm 159.9$ \\
lividus & Coastal & $56 \pm 26.6$ & $58 \pm 33.6$ \\
& Frontal & $15 \pm 11.7$ & $55 \pm 29.8$ \\
Acartia clausi & Oceanic & $156 \pm 131.8$ & $139 \pm 44.8$ \\
& Coastal & $66 \pm 13.5$ & \\
& Frontal & $22 \pm 3.8$ & \\
& Oceanic & $14 \pm 3.2$ & \\
\hline
\end{tabular}

bon:chlorophyll ratio for the whole water column of 40 (Delgado et al. 1992, L. Arin pers. comm.), and considering a gross growth efficiency of $40 \%$ (Kiørboe et al. 1985). The lowest clearances corresponded to the copepod Clausocalnus lividus at the frontal stations (both years), whereas the highest rates were observed for Centropages typicus also at the frontal stations (Hivern-00). In general, the clearance rates calculated are realistic, and close to maximum attainable rates for copepods of similar size feeding on algae $(\sim 100 \mathrm{ml}$ copepod $^{-1} \mathrm{~d}^{-1}$ for Acartia tonsa, Berggreen et al. 1988, Kiørboe et al. 1996; or $\sim 50 \mathrm{ml} \operatorname{copepod}^{-1} \mathrm{~d}^{-1}$ for $C$. typicus, Tomasini \& Mazza 1979). An exception to this were the values for $C$. typicus during Hivern-00, indicating that autotrophic food ingestion was not enough to cover the carbon requirements for egg production, and that other heterotrophic food species are ingested. Ciliate abundance alone, however, seems insufficient to explain the EPR found in Hivern-00. Assuming size (20 $\mu \mathrm{m}$ diameter) and abundance $\left(2\right.$ cells $\left.\mathrm{ml}^{-1}\right)$ of ciliates for the NW Mediterranean during winter (Vaqué et al. 2001), and a daily clearance rate for adult $C$. typicus of $200 \mathrm{ml} \mathrm{copepod}^{-1} \mathrm{~d}^{-1}$ (Caparroy et al. 1998), we would expect a contribution of ca. 3 eggs fem ${ }^{-1} d^{-1}$ on EPR due to ciliate ingestion, which is not enough to explain the EPR of Hivern-00. Hence, other factors such as turbulence, which has been shown to increase clearance rates upon ciliates by as much as a factor of 4 (Saiz \& Kiørboe 1995, Caparroy et al. 1998), and organismal aggregation in patches (Mackas et al. 1985, George 1989, Davis et al. 1991, Montagnes et al. 1999) could be involved.

\section{Comparison of winter and summer environments}

While during summer stratification primary production is confined to certain water layers in which there is a trade-off between light intensity and nutrient availability, during winter, or in general in well-mixed waters, phytoplankton is more evenly distributed, and at times more abundant (Hivern-99). It seems, however, that the biomass of mesozooplankton supported by unit of phytoplankton biomass was lower in winter, denoting a less efficient food web. Yet, the winter mesozooplankton community was highly productive, indicating more likely zooplankton losses possibly by predation or advection. Although advective losses cannot be rejected, the presence of active predators of zooplankton, like sardine larvae, during winter months (Palomera \& Olivar 1996) may be a main cause suppressing a more numerous zooplankton community.

Besides stratification, temperature is one of the most relevant factors determining seasonal differences in physiological processes in temperate latitudes. How- 


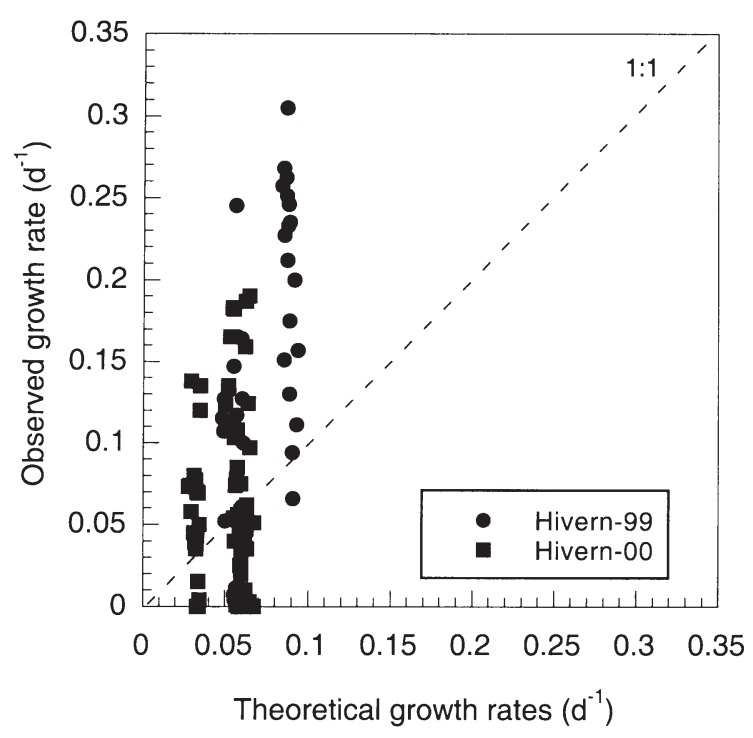

Fig. 8. Relationships between experimental and theoretical weight-specific growth rates. The theoretical estimates have been obtaining using the model of Hirst \& Lampitt (1998) based on temperature and organismal size. Line 1:1 is also indicated

ever, the higher copepod EPR in winter in the present study indicates that production rates were weakly influenced by temperature compared with other variables, such as food availability. Accordingly, the use of recent models predicting EPR from temperature and organism size (Huntley \& Lopez 1992, Hirst \& Lampitt 1998) greatly underestimate the production observed (Fig. 8). This is indicative of a higher importance of food concentration in front of temperature as driver of EPR (Calbet \& Agustí 1999) and denotes that the copepods in this system are physiologically adapted to the environmental temperature to maintain maximum growth rates if sufficient food is available.

Studies in NW Mediterranean coastal areas, like the Gulf of Naples, also report higher copepod production during February-March, with values of EPR similar to the ones found in our study (Ianora \& Buttino 1990, Ianora et al. 1992). More recent works showing lower EPR year-round (Halsband-Lenk et al. 2001, Ligurian Sea) seem to be biased by the use of filtered seawater to incubate copepod females (Saiz et al. 1997). Regardless, it is remarkable that our EPRs from open-ocean waters compare with, or are even higher than, coastal EPRs. How these high productions are maintained with the available prey concentration has been discussed above, but there are some noteworthy differences between seasons. Ciliate abundance and biomass seem to show a recurrent minimum in coastal NW Mediterranean areas during winter months (Vaqué et al. 1997, Modigh 2001), while phytoplankton produces intermittent blooms and higher concentrations
(Estrada et al. 1999, this study). This situation could result in a greater proportion of heterotrophs in the diet of zooplankton during periods of scarcity of autotrophs (e.g. summer), and therefore in a higher relevance of microbial food webs. In contrast, during the winter phytoplankton bloom, when water is richer in autotrophic food, plankton interactions must be mediated through a shorter, and more efficient, food chain (copepods-phytoplankton). Proof of this can be found in the higher coupling between copepod production and phytoplankton biomass during this study, in contrast with previous records during summertime.

In summary, our data from the NW Mediterranean depict a highly productive copepod community feeding mostly on autotrophs during phytoplankton bloom conditions. This situation contrasts with the planktonic community from the rest of the year, in which the phytoplankton is less abundant, and copepods tend to grow at lower rates, probably taking a good portion of their nourishment from heterotrophic organisms.

Acknowledgements. The authors are indebted to A. Sabatés, who conducted part of the on board pigment analysis, R. Retamal, who took care of the of pigment analysis in the laboratory and counted the eggs for EPR, F. Pagés, who measured copepod eggs, M. Emelianov for his help with the physical data, and to the rest of the participants on the cruises Hivern-99 and Hivern-00 for their occasional assistance. We also thank X. Irigoien and R. Scheinberg, whose comments improved the manuscript. Financial support was provided by the projects MAR98-0932 and MAR98-0854.

\section{LITERATURE CITED}

Alcaraz M, Packard TT (1989) Zooplankton ETS activity and respiration in the Catalan Sea (western Mediterranean). Sci Mar 53:247-250

Alcaraz M, Saiz E, Estrada M (1994) Excretion of ammonia by zooplankton and its potential contribution to nitrogen requirements for primary production in the Catalan Sea (NW Mediterranean). Mar Biol 119:69-76

Berggreen U, Hansen B, Kiørboe T (1988) Food size spectra ingestion and growth of the copepod Acartia tonsa during development: implications for determination of copepod production. Mar Biol 99:341-352

Cacciamani C, Nanni S, Nucciotti F, Paccagnella T (1992) In: Vollenweider RA, Marchetti R, Viviani R (eds) Marine coastal eutrophication science of the total environment. Suppl, p 159-170

Calbet A, Agustí S (1999) Latitudinal changes of copepod egg production rates in Atlantic waters: temperature and food availability as the main driving factors. Mar Ecol Prog Ser 181:155-162

Calbet A, Alcaraz M, Saiz E, Estrada M, Trepat I (1996) Planktonic herbivourous food webs in the Catalan Sea (NW Mediterranean): temporal variability and comparison of indices of phyto-zooplankton coupling based in state variables and rate processes. J Plankton Res 18: 2329-2347 
Calbet A, Garrido S, Saiz E, Alcaraz M, Duarte CM (2001) Annual zooplankton succession in coastal NW Mediterranean waters: the importance of the smaller size fractions. J Plankton Res 23:319-331

Caparroy P, Perez M T, Carlotti F (1998) Feeding behaviour of Centropages typicus in calm and turbulent conditions. Mar Ecol Prog Ser 168:109-118

Castellón A, Font J, Garcia-Ladona E (1991) The LiguroProvençal-Catalan current (NW Mediterranean) observed by Doppler profiling in the Balearic Sea. Sci Mar 54: 269-276

Chisholm LA, Roff JC (1990) Size-weight relationships and biomass of tropical neritic copepods off Kingston, Jamaica. Mar Biol 106:71-77

Dagg M (1977) Some effects of patchy food environments on copepods. Limnol Oceanogr 22:99-107

Davis CS, Alatalo P (1992) Effects of constant and intermittent food supply on life-history parameters in a marine copepod. Limnol Oceanogr 37:1618-1639

Davis CS, Flierl GR, Wiebe PH, Franks PJS (1991) Micropatchiness turbulence and recruitment in plankton. J Mar Res 49:109-151

Delgado M, Latasa M, Estrada M (1992) Variability in the size-fractionated distribution of the phytoplankton across the Catalan front of the north-west Mediterranean. J Plankton Res 14(5):753-771

Duarte CM, Agustí S, Kennedy H, Vaqué D (1999) The Mediterranean climate as a template for Mediterranean marine ecosystems: the example of the NE Spanish littoral. Prog Oceanogr 44:245-270

Durbin EG, Durbin AG (1978) Length and weight relationships of Acartia clausi from Narragansett Bay, RI. Limnol Oceanogr 23:958-969

Estrada M, Margalef R (1988) Supply of nutrients to the Mediterranean photic zone along a persistent front. In: Minas HJ, Nival P (eds) Océanographie pélagique Méditerranéenne. Oceanologica Acta $N^{\circ}$ SP 9:133-142

Estrada M, Varela RA, Salat J, Cruzado A, Arias E (1999) Spatio-temporal variability of the winter phytoplankton distribution across the Catalan and North Balearic fronts (NW Mediterranean). J Plankton Res 21:1-20

George DG (1989) Zooplankton patchiness in enclosed and unenclosed areas of water. J Plankton Res 11:173-184

Halsband-Lenk C, Nival S, Carlotti F, Hirche HJ (2001) Seasonal cycles of egg production of two planktonic copepods, Centropages typicus and Temora stylifera, in the north-western Mediterranean Sea. J Plankton Res 23: $597-609$

Hirst AG, Lampitt RS (1998) Towards a global model of in situ weight/specific growth in marine planktonic copepods. Mar Biol 132:247-257

Hopcroft RR, Roff JC (1998) Zooplankton growth rates: the influence of female size and resources on egg production of tropical marine copepods. Mar Biol 132:79-86

Huntley ME, Lopez MDG (1992) Temperature dependent production of marine copepods: a global synthesis. Am Nat 140:201-242

Ianora A, Buttino I (1990) Seasonal cycles in population abundances and egg production rates in the planktonic copepods Centropages typicus and Acartia clausi. J Plankton Res 12:473-481

Ianora A, Scotto di Carlo B (1988) Observations on egg production rates and seasonal changes in the internal morphology of Mediterranean populations of Acartia clausi and Centropages typicus. Hydrobiologia 167/168: $247-253$

Ianora A, Mazzocchi MG, Grottoli R (1992) Seasonal fluctua- tions in fecundity and hatching success in the planktonic copepod Centropages typicus. J Plankton Res 14: $1483-1494$

Kiørboe T, Mohlenberg F, Hamburger K (1985) Bioenergetics of the planktonic copepod Acartia tonsa: relation between feeding, egg production and respiration and composition of specific dynamic action. Mar Ecol Prog Ser 26: 85-97

Kiørboe T, Saiz E, Viitasalo M (1996) Prey switching behaviour in the planktonic copepod Acartia tonsa. Mar Ecol Prog Ser 143:65-75

Le Ruyet-Person J, Razouls C, Razouls S (1975) Biologie comparée entre espèces vicariantes et communes de copépodes dans un écosystème néritique en Méditerranée et en Manche. Vie Milieu 25:283-312

Mackas DL, Denman KL, Abbott MR (1985) Plankton patchiness: biology in the physical vernacular. Bull Mar Sci 37: 652-674

Margalef R, Estrada M (1987) Synoptic distribution of summer microplankton (algae and protozoa) across the principal front in western Mediterranean. Invest Pesq 51: 121-140

Modigh M (2001) Seasonal variations of photosynthetic ciliates at a Mediterranean coastal site. Aquat Microb Ecol 23:163-175

Modigh M, Saggiomo V, d'Alcalà R (1996) Conservative features of picoplankton in a Mediterranean eutrophic area, the Bay of Naples. J Plankton Res 18:87-79

Montagnes DJS, Poulton AJ, Shammon TM (1999) Mesoscale, finescale and microscale distribution of micro- and nanoplankton in the Irish Sea, with emphasis on ciliates and their prey. Mar Biol 134:167-179

Mura MP, Agustí S, Cebrián J, Satta MP (1996) Seasonal variability of phytoplankton biomass and community composition in Blanes Bay (1992-1994). Publ Espec Inst Esp Oceanogr 22:23-29

Palomera I, Olivar P (1996) Nearshore ichthyoplankton off the Costa Brava (northwest Mediterranean Sea). Publ Espec Inst Es Oceanogr 22:71-75

Parsons TR, Maita Y, Lalli CM (1984) A manual of chemical and biological methods for sea water analysis. Pergamon Press, Oxford

Razouls S (1975) Fécondité, maturité sexuelle et différenciation de l'appareil génital des femelles de deux Copépodes planctoniques: Centropages typicus et Temora stylifera. PSZN I: Mar Ecol 39(Suppl):297-306

Razouls S (1982) Étude expéimentale de la ponte de deux copépodes pélagiques Temora stylifera et Centropages typicus. II. Dynamique des pontes. Vie Milieu 32:11-20

Saiz E, Calbet A (1999) On the free-spawning reproductive behaviour of the copepod Clausocalanus lividus (Frost \& Fleminger 1968). J Plankton Res 21:599-602

Saiz E, Kiørboe T (1995) Predatory and suspension feeding of the copepod Acartia tonsa in turbulent environments. Mar Ecol Prog Ser 122:147-158

Saiz E, Rodriguez V, Alcaraz M (1992) Spatial distribution and feeding rates of Centropages typicus in relation to frontal hydrographic structures in the Catalan Sea (western Mediterranean). Mar Biol 112:49-56

Saiz E, Calbet A, Trepat I, Irigoien X, Alcaraz M (1997) Food availability as a potential source of bias on the egg production method for copepods. J Plankton Res 19:1-14

Saiz E, Calbet A, Irigoien X, Alcaraz M (1999) Copepod egg production in the western Mediterranean: response to food availability in oligotrophic environments. Mar Ecol Prog Ser 187:179-189

Tomasini JA, Mazza J (1979) Comportement alimentaire de 
deux copépodes calanoides (Centropages typicus et Acartia clausi) en mulieux nutritifs á une seule algue. J Cons Perm Int Explor Mer 38:154-179

Uye S (1981) Fecundity studies of neritic calanoid copepods Acartia clausi Giesbrecht and A. steueri Smirnov: a simple empirical model of daily egg production. J Exp Mar Biol Ecol 50:255-271

Uye S, Yamaoka T, Fusijawa T (1992) Are tidal fronts good recruitment areas for herbivorous copepods? Fish Oceanogr 1:3:216-226

Vaqué D, Blough HA, Duarte CM (1997) Dynamics of ciliate

Editorial responsibility: Otto Kinne (Editor), Oldendorf/Luhe, Germany abundance, biomass and community composition in an oligotrophic coastal environment (NW Mediterranean). Aquat Microb Ecol 12:71-83

Vaqué D, Casamayor EO, Gasol JM (2001) Dynamics of whole community bacterial production and grazing losses in seawater incubations as related to the changes in the proportions of bacteria with different DNA-content. Aquat Microb Ecol 25:163-177

Welschmeyer NA (1994) Fluorometric analysis of chlorophyll $a$ in the presence of chlorophyll $b$ and pheopigments. Limnol Oceanogr 39:1985-1992

Submitted: September 14, 2001; Accepted: March 21, 2002 Proofs received from author(s): June 27, 2002 